\title{
REGIONAL EFFECTS ON THE CAPITAL STRUCTURE OF THE ITALIAN SMES.
}

by G. Cinquegrana, Italian Institute of Statistic (ISTAT), Italy. gcinque@istat.it

D. Sarno, Università della Campania, "L. Vanvitelli”, Italy, domenico.sarno@unicampania.it

\section{ABSTRACT}

The paper aims to investigate on the determinants of the capital structure of the Italian SMEs and it is based on a large panel of Italian manufacturing SMEs observed in the years 2001-2013. The analysis achieves a comparative investigation between the capital structure of the firms belonging in the Southern region, the so-called Italian Mezzogiorno that is the slow growing area of the country, and the firms of the Centernorthern region of Italy, that is the more developed area of the country. Fixed effect panel techniques applied to the several standard leverage models allows to reaffirm some distinctive features showing differences of the financial behavior of regional firms.

Keywords: capital structure, corporate finance, leverage model, fixed effect panel

JEL: G32, G30, L60 


\section{REGIONAL EFFECTS ON THE CAPITAL STRUCTURE OF THE ITALIAN SMES.}

\section{INTRODUCTION}

The aim of this study is to analyse the capital structure of SMEs in areas with slower economic and social growth rates compared with the capital structure of SMEs in more developed areas to identify any distinctive features. Our empirical test field is represented by the so-called Italian Mezzogiorno, that is, the least developed area in the country. The Mezzogiorno or southern regions refer to the historically well-defined area that includes the eight administrative regions of the southern part of Italy (Abruzzo, Molise, Campania, Puglia, Basilicata and Calabria) and the two Islands (Sicily and Sardinia). ${ }^{1}$ In contrast, the centralnorthern regions refer to the other twelve administrative regions of the central and northern areas of Italy. ${ }^{2}$

There are numerous reasons for the existence of some noticeable differences in the capital structure of firms from areas with different levels of development. Factors relating to the institutional environment, industrial composition and life cycle of firms and to the level of development and integration of financial and bank markets are generally cited (La Porta et al., 1997, 1998; Levine, 1997, 2004; Beck et al., 2003, 2005).

Therefore, although the differences in the institutional and socio-economic environments are not negligible, the idea that is generally accepted by comparative analyses of the capital structure is that the variables explaining the capital structure of firms in the more developed regions can also explain the capital structure of firms in backward areas. Moreover, there are observable patterns in the capital structure involving both large and small firms; for example, profitable firms tend to show lower leverage, the higher the fixed assets are, the higher the long-term debts are and so on (Rajan and Zingales, 1995; Wald, 1999; Booth et al., 2001).

Using a very large panel observed over the period 2001-2013, this study is also able to examine the effects on the capital structure caused by the credit supply shock of the financial crisis of 2007-2008. The theoretical predictions agree that, after a credit supply shock, firms are forced to meet their financial needs through alternative sources. While large firms can easily absorb the impact of a credit squeeze, because they can use alternative sources, the opacity and risk condition hinder smaller firms' access to non-bank financial sources; their leverage therefore decreases. Moreover, it can be predicted that the composition of the debt will change. Since there will be little probability of resorting to equity,

\footnotetext{
1 It corresponds to the ITF (South Italy) and ITG (Insular Italy) areas of the NUTS 1 classification for Italy adopted by the EU statistical system (Eurostat). With the exception of Abruzzo and Molise, six of the eight southern regions of the Italian Mezzogiorno were included in the "Objective 1" areas of the EU and received EU flows to promote development (so-called structural funds). It is known that the 2007-2013 EU planning was replaced by "Objective Convergence", which includes the regions with a GDP per capita less than $75 \%$ of the average EU GDP per capita. The convergence program involves four Italian regions, Campania, Puglia, Calabria, and Sicily, while the Basilicata and Sardinia regions are temporarily included in the "phasing-out" and the "phasing-in" status, respectively.

${ }^{2}$ It is formed by the regions classified by the NUTS 1 nomenclature as ITC (Northwest Italy), ITH (Northeast Italy), and ITI (Central Italy).
} 
the share of long-term debt will tend to increase despite the drop in the total debts (Wald, 1999; Booth et al., 2001; Beattie et al., 2006).

The next investigation tries to apply these analytical guides to the capital structure of small and medium-sized firms (SMEs) in the Southern Italian regions. In the past, several factors could give rise to distinctive characteristics in the financial structure of firms, particularly small firms, some of which have disappeared. On the one hand, the early 1990s' "extraordinary intervention" to promote the growth of southern regions and the public agency for infrastructural policies have ceased. On the other hand, the reforms of the national banking system involved the big national banks in the concentration of and progressive integration into the European banking system; consequently, the large regional southern banks, which previously had played an important role in promoting local growth, disappeared.

In fact, empirical analysis of Mezzogiorno economics suggests that the financial structure of Southern Italian firms, especially smaller ones, showed some distinctive features in those years. They appeared to be burdened by excessive debt, particularly in the short term, and at the same time suffered from undercapitalization (Mediocredito Centrale, 1997, 2000). Other analyses find that, from the mid-1990s, there have been noticeable variations in the financial structure of local firms, caused by the institutional reorganization taking place at the start of the decade. The financial structure of southern firms appears to be convergent with that of their counterparts in the other Italian regions. This convergence was due to both real and financial effects: on the one hand, the increasing competitive pressure on southern firms arising from the cessation of the extraordinary policies and, on the other hand, the credit supply shock following the dissolution of the regional banking system (Capitalia, 2002, 2005).

The paper is organized as follows. The next section sets out the data set's features and the data sources. Some of the stylized facts regarding the financial structure of southern SMEs are examined in the third section. The fourth section analyses the determinants of the capital structure of SMEs and discusses some arguments emerging from the main theoretical approaches. The empirical model and the variable specifications are found in the fifth section, while the sixth section offers an interpretation of the empirical outcomes. Some concluding remarks make up the last section.

\section{SOURCES AND CHARACTERISTICS OF THE DATA SET}

The data set for the following analysis is made up of a large panel of Italian manufacturing firms with more than 10 employees observed for the 2001-2013 period. The sources of the data are the archives of the Statistical National Institute (ISTAT). The sample firms are extracted from the Statistical Firms Register (ASIA) and are classified in accordance with the main activity sector (ISIC Rev. 4) at the two-digit level. ${ }^{3}$ The

\footnotetext{
3 Since 1996, the Statistical Firms Register (ASIA) of the Statistical National Institute (ISTAT) has gathered structural information on economic unity in industrial, trading and service activities. The register is revised annually through the expansion of the various statistical archives, and it represents the universe referred to by the ISTAT analysis of Italian firms. The information in the database can be classified as (i) ID variables
} 
manufacturing firms, based on the NACE classification of economic activities (ATECO, 2007), are marked by 10-33 codes. The data come from individual firm data sheets supplemented by other information, for example date of birth, property, workforce composition, exports and so on.

The data set is an unbalanced panel, because

a) not all the firms are represented in every year;

b) not all the data of individual firms are available for every year.

The data are initially restricted to small and medium enterprises (SMEs) according to the EU statistical criteria. ${ }^{4}$ This sample arises from an annual average of about 39,000 firms; it potentially collects about 570,000 observations.

For the purposes of this analysis, this data set presents two problems. The first regards the sourcing of the data from the firms' statements. The accounting rules permit smaller firms to post a so-called "short budget" - a simplified financial statement that allows the omission of otherwise compulsory information. ${ }^{5}$ For our purposes, the most important difference is that the short budget only provides data on total liabilities, and it is possible to distinguish only between short-term liabilities and long-term liabilities; in addition, it is not possible to gauge the amount of financial debt or the amount of bank debt. This bias prevents us from making use of conventional leverage measures for many observations.

There is a second question regarding the period analysed. As we know, the later part coincides with the financial crisis and the consequent dramatic fall in production. Naturally, the firms' financial statements for these years reflect the effects of these exceptional events. This leads to a potential bias in several of the financial ratios used for the empirical analysis, especially the profit ratios. To avoid these sources of possible bias, the firms that post "short budgets" are removed from the original data set; then, to tackle the second source of bias, we restrict the analysis to profitable firms only.

Therefore, the data set used for the following analysis is based on an annual average of more than 33,000 firms; for the whole 2001-2013 period, the total potential sample units amount to about 427,500 . The 58,000 southern SMEs make up $13.5 \%$ of the sample; the remaining firms from the other Italian regions add up to about 370,000 (Table 1).

(corporate name, address, etc.), (ii) stratification variables (ISIC activities, employment size, sale size, etc.) and (iii) demographic variables (date of birth and death, mergers and acquisitions, bankruptcy, etc.).

${ }^{4}$ In accordance with the EU recommendation 2003/3061/CE that lays down the criteria distinguishing micro, small, and medium-sized firms applied from 2005, SMEs are firms with 50-249 employees and total balance sheets of less than 43 million euros. As we have indicated, micro firms (with fewer than 10 employees) are not included in the sample.

${ }^{5}$ Compared with the complete sheet, the "short budget" simplifies the posting of the Statement of Assets, Profit and Loss Account and Integrative Note, and it authorizes the possible exemption of the Management Report. The latest rules were introduced in 2008 and effective from 2009. The "short" budget can be submitted by companies that have not issued their bonds in regulated markets and that do not exceed, for the first trading year or for the two next trading years, two of the following limits:

- $\quad$ assets of 4 million euros;

- $\quad$ sales of 8 million euros;

- $\quad$ annual average number of employees below 50 . 


\begin{tabular}{|l|r|r|r|c|}
\hline \multicolumn{5}{|l|}{ Tab. 1 - Sample composition for industry and sized classes } \\
\hline & ITALY & SOUTH & NORTH & $\%$ SOUTH \\
\hline FOOD & 29668 & 9718 & 19950 & 0,328 \\
DRINK \& TOBACCO & 5970 & 2109 & 3861 & 0,353 \\
TEXTILE & 22034 & 1278 & 20756 & 0,058 \\
CLOTHING & 19122 & 3392 & 15730 & 0,177 \\
SKIN \& SHOES & 15053 & 2020 & 13033 & 0,134 \\
WOOD & 13618 & 2120 & 11498 & 0,156 \\
PAPER & 9869 & 1402 & 8467 & 0,142 \\
EDITING & 14436 & 1655 & 12781 & 0,115 \\
PETROLEUM & 1467 & 621 & 846 & 0,423 \\
CHEMISTRY & 14332 & 2040 & 12292 & 0,142 \\
PHARMACEUTICAL & 2187 & 189 & 1998 & 0,086 \\
RUBBER \& PLASTIC & 25589 & 2865 & 22724 & 0,112 \\
GLASS \& CERAMICS & 28254 & 7267 & 20987 & 0,257 \\
METALLURGY & 11456 & 1287 & 10169 & 0,112 \\
MECHANICS & 70060 & 7765 & 62295 & 0,111 \\
ELECTRONICS & 12422 & 1029 & 11393 & 0,083 \\
ELECTRICAL & 15936 & 1134 & 14802 & 0,071 \\
MECHINERY & 56252 & 2763 & 53489 & 0,049 \\
CAR AND ENGINE & 6292 & 895 & 5397 & 0,142 \\
OTHER TRANSPORT & 3316 & 549 & 2767 & 0,166 \\
FURNITURE & 18697 & 1749 & 16948 & 0,094 \\
OTHER MANUFACTURING & 13510 & 966 & 12544 & 0,072 \\
REPAIR INDUSTRY & 17928 & 3276 & 14652 & 0,183 \\
\hline TOTAL & 427468 & 58089 & 369379 & 0,136 \\
\hline SOUIC: IIalin InStIt
\end{tabular}

Source: Italian Institute of Statistics (ISTAT)

\section{THE MAIN FEATURES OF THE FINANCIAL STRUCTURE OF SOUTHERN SMES}

The empirical analysis shows that there are some noticeable differences in the regional financial structure of the SMEs. They are explained by regional effects arising from the regional institutional environment and particularly from the development degree of the local financial system.

Applying panel methods to a sample of Spanish firms from all regions for the years 2004-2007, Palacin-Sanchez et al. (2013) find that there are regional differences in SMEs' capital structure; moreover, they confirm that the determinants of the firm leverage differ across regions. In a more recent analysis (2016), these authors examine the impact of the regional financial and banking systems on the leverage of Spanish SMEs; they show that the capital structure depends on both the development and the competition degrees of financial and banking systems.

Using a sample of Portuguese SMEs observed in the years 2007-2011, Matias and Serrasqueiro (2017) find that firms' capital structure differs across regions of Portugal. Nevertheless, they conclude that there are no statistically significant differences in terms of both the direction and the magnitude of the main determinants of SMEs' regional leverage.

With reference to the cross-regional analysis of Italian SMEs, Sarno $(2008,2009)$ and Donati and Sarno (2015) confirm that there are remarkable differences in the regional financial structure of the SMEs and that they make the firms of Southern Italy more financially constrained and firms' growth more dependent on internal finance. Moreover, they find that firms' financial structure is significantly affected by the development of the local banking systems as well as by the efficiency of the local legal systems. In their study, la Rocca et al. (2011) reaffirm that firms' capital choices are affected by the local institutional environment, such as both the financial development and the legal enforcement system. 
From a different perspective, Presbitero et al. (2014) support the idea that the capital structure of the SMEs is affected by the local banking markets; they show that the credit crunch following financial crises is exacerbated by the functional distance of the banks, particularly in the southern regions, where the share of branches owned by distantly managed banks is larger.

To mark these differences, Table 2 shows the median values of some equity indices regarding the leverage components: firms' equity and debts. It also contains the ratios for two sub-periods: prior to (2001-2007) and subsequent to (2008-2013) the explosion of the financial crisis.

The indices show that the equity ratios in the upper part of the table are systematically higher for southern SMEs. This picture contrasts quite clearly with the widely accepted idea that firms in backward regions are undercapitalized. With regard to the debt levels, the ratios in the lower part confirm the higher indebtedness of the southern SMEs,.

The ratios for the two sub-periods highlight the altered conditions of the financial and credit markets after the dramatic credit supply squeeze. Specifically, they help to clarify that the southern firms have suffered especially from the effects of the credit crunch; it has caused a radical change in the relative position regarding the debt-equity ratio in more recent years. In particular, the bank debt ratio, which seems to have recovered partially in the more recent period, shows that the short-term debts are following a downward trend, particularly for southern firms.

\begin{tabular}{|c|c|c|c|c|c|c|c|c|c|}
\hline \multirow[b]{2}{*}{ Equity ratios } & \multicolumn{3}{|c|}{ 2001-'13 } & \multicolumn{3}{|c|}{ 2001-'07 } & \multicolumn{3}{|c|}{ 2008-'13 } \\
\hline & ITALY & SOUTH & NORTH & ITALY & SOUTH & NORTH & ITALY & SOUTH & NORTH \\
\hline EQUITY_VALUE ADDED ('000) & 353,1 & 490,1 & 340,3 & 314,8 & 445,8 & 303,0 & 427,5 & 625,9 & 432,8 \\
\hline EQUITY_EMPLOYEES ('000) & 4106,4 & 5236,6 & 3968,8 & 3328,4 & 4651,4 & 3201,9 & 5463,2 & 5893,6 & 5293,2 \\
\hline EQUITY_ASSETS (\%) & 71,1 & 68,8 & 71,5 & 73,9 & 70,4 & 73,4 & 67,2 & 66,2 & 67,6 \\
\hline FIXED ASSETS_ASSETS (\%) & 19,7 & 29,9 & 18,4 & 20,2 & 28,7 & 16,7 & 18,0 & 29,1 & 21,3 \\
\hline \multicolumn{10}{|l|}{ Debt ratios } \\
\hline TOTAL FINANCIAL DEBT_VALUE ADDED (\%) & 387,2 & 523,3 & 372,3 & 398,0 & 509,2 & 384,6 & 368,7 & 551,1 & 350,9 \\
\hline TOTAL FINANCIAL DEBT_EQUITY (\%) & 109,1 & 104,6 & 109,8 & 126,9 & 113,4 & 123,9 & 89,5 & 94,0 & 88,7 \\
\hline SHORT-TERM ON TOTAL FINANCIAL DEBT (\%) & 89,0 & 83,9 & 89,7 & 90,4 & 86,2 & 90,1 & 87,0 & 80,2 & 86,3 \\
\hline TOTAL BANK ON_TOTAL FINANCIAL DEBT (\%) & 49,6 & 45,4 & 50,3 & 51,1 & 45,8 & 51,8 & 47,7 & 45,0 & 48.1 \\
\hline
\end{tabular}

Source: Italian Institut of Statistics (ISTAT)

\section{THE DETERMINANTS OF THE CAPITAL STRUCTURE}

Despite the extensive empirical studies carried out on these subjects, no one theory of capital structure is unanimously accepted. ${ }^{6}$ A wide range of theoretical approaches derived from the seminal work by Modigliani-Miller removes some of the conditions imposed by the "irrelevance theorem", thereby allowing consideration of, for example, agency costs (Jensen and Meckling, 1976; Myers, 1977; Harris and Raviv, 1990), information asymmetry

\footnotetext{
${ }^{6}$ Most empirical studies are devoted to investigating the determinants of firms' capital structure in various countries. Among the latest studies not cited in the text are: De Miguel and Pindado (2001) for Spain, Colombo (2001) for Hungary, Bradmi (2002) for India, Chen (2004) and Tong et al. (2005) for China, Gand (2005) for Switzerland, Mazur (2007) for Poland, Yu and Aquino (2009) for the Philippines and Quresh (2009) for Pakistan.
} 
and signalling (Ross, 1977; Myers, 1984; Myers and Majluf, 1984) or taxes (Miller, 1977; De Angelo and Masulis, 1980).

The analytical strength of these approaches is dependent on the elements that are considered, but the so-called trade-off and pecking-order theories are most frequently evoked. The trade-off theory places the emphasis on taxation, while the pecking order theory argues the asymmetric condition of information and agency costs. These aspects are all considered to be equally relevant to the financial strategies of the firm, but it seems that none of the previous approaches proposes an exhaustive explanation of firms' financial choices, although empirical research is frequently consistent with several of them.

Moreover, there is wide agreement that the previous approaches are equally effective in the analysis of large firms and smaller firms, even though the arguments proposed by the informative asymmetry theory are generally more suitable for the analysis of SMEs. There are several reasons for this belief, primarily that smaller firms are more dependent on external finance, especially bank debts, and the information relationship with lenders therefore becomes crucial (Booth et al., 2001; Cassar and Holmes, 2003; Beattie et al., 2006).

Empirical analysis is generally conducted to identify the main determinants of the capital structure of SMEs, and there is unanimous agreement that the determinants primarily include size, age and profitability. The impacts of size on the capital structure are numerous, but in all cases they are consistent with the idea that, when the size increases, the debt share increases. Empirical analysis generally verifies a positive relationship between firm size and leverage and sometimes a negative relationship for short-term debt (Chittenden et al., 1996; Michaels et al., 1999; Noulas and Genimakis, 2011).

With regard to firm age, the arguments from the informative asymmetry theory prevail; this approach is in favour of a positive relationship between leverage and firm age; in contrast, the theory of the firm life cycle proposes a non-linear relationship between leverage and age (Berger and Udell, 1998). In fact, both positive and negative relationships are found by most empirical studies (Beattie et al., 2006; Daskalaki and Psillaki, 2008; La Rocca et al., 2011; Noulas and Genimakis, 2011).

Of all the theories, the pecking order theory best explains the relationship between leverage and profitability. Firms have a greater propensity to use internal resources because external finance is more expensive; consequently, a negative relationship might prevail between leverage and earnings. The relationship becomes unclear when a distinction is made between short-term and long-term debts. The empirical evidence generally shows that leverage is correlated negatively with the profit rate, but the relationship can be positive or negative distinguishing between short- and long-term debts (Rajan and Zingales, 1995; Adedeji, 1998; Michaelas et al., 1999; Hall et al., 2004).

Among the other determinants involved in most of the empirical analyses are the growth rate, the asset structure and the individual risk. The growth rate approximates investment opportunities, and its relationship with leverage is ambiguous; it is negative because self-financing is the preferred way to fund firm growth, while alternatively it is positive because profitable firms are able to achieve higher earnings and can therefore sustain higher debt costs. The empirical evidence is compatible with both the approaches, because the relationship is sometimes found to be positive and sometimes negative (Psillaki and Deskalakis, 2009; Noulas and Genimakis, 2011). 
The asset structure, as measured by the fixed asset share, is of considerable importance, because greater fixed assets used as collateral might give firms easier access to external finance. Based on these arguments, we can expect a positive relationship between asset structure and long-term debt, while the relationship with short-term debt might be negative (Rajan and Zingales, 1995; Chittenden et al., 1996; Jordan et al., 1998; Michaels et al., 1999; Frank and Goyal, 2003).

Finally, we can theoretically predict a close negative relationship between leverage and firm risk, because higher debt causes higher volatility of earnings, and empirical analyses generally confirm this belief (Cassar and Holmes, 2003; Hall et al., 2004; Psillaki and Deskalakis, 2009).

\section{THE EMPIRICAL MODEL}

The following analysis is based on the four specifications of the dependent variable, leverage (LEV):

1) total financial debt/equity (TFD/EQU);

2) short-term financial debt/equity $(S F D / E Q U)$;

3) long-term financial debt/equity ( $L F D / E Q U)$;

4) total bank debt/equity (TBD/EQU).

The explicative variables are: size, age, profitability, growth, asset structure and risk.

a) Size (SIZE) is preliminarily approximated by two measures: a) the total assets (ASSETS) and $b$ ) the annual average number of employees (EMPLOYMENT);

b) Age $(A G E)$ is measured by the number of years from the firm's start to the observation years;

c) The growth rate (GROW) is equal to the annual percentage variation in the total assets as measured by the difference between the natural logarithm of assets of the i-year and that of the i-1-year;

d) Profitability (PROF) is expressed by three profit rates: a) the return on investment measured by the gross profit on investment (equity plus total debt) $\left(P R O_{1}=R O I\right)$ and $b)$ the return on equity measured by the net profit on equity $\left(P R \mathrm{O}_{2}=R O E\right)$;

e) The asset structure (TANG) is equal to the share of fixed assets over total assets;

f) Risk $(R / S K)$ is measured by the standard deviation of the profit rates.

The estimates are based on the total sample (ITALY) and on the two macro-region subsamples of the central-northern Italian regions (NORTH) and the Mezzogiorno regions (SOUTH). The ITALY model is supplemented with a dummy variable to capture the leverage differentials between two firms belonging to the different macro-regions. Therefore, it is necessary to consider the following variable:

g) Regional dummy (REG): a dummy assuming the unit value for the observations of the southern firms and zero value otherwise.

The empirical model is as follows: 
[1]

$$
L E V^{s}=\beta^{1} S_{Z I E E_{i, j, h}}+\beta^{2} A G E_{i, j, h}+\beta^{3} G R O W_{i, j, h}+\beta^{4} P R O F_{i, j,}^{S}+
$$

$\beta^{5} T A N G_{i, j, h}+\beta^{6} R I S K_{i, j, h}+\beta^{7} R E G_{i, j, h}+\alpha_{i}+\alpha_{J}+\alpha_{h}+\mu_{i, j}$

where $\beta$ coefficients are relative to the $i$-th firm of the $h$-th manufacturing industry for the $j$-th year; the peak $s$ indicates the different specifications of the variable and $\alpha_{i}, \alpha_{J}$ and $\alpha_{h}$ are the individual, temporal and industrial effects; and $\mu_{i, j, h}$ is the error term.

The empirical analysis is restricted to profitable firms to avoid possible biases arising from the dramatic alteration in firms' data caused by the explosion of the financial crisis. Therefore, all the variables are expressed in natural logarithm; the estimated coefficients must be interpreted as the elasticity of the variables in relation to firm leverage. ${ }^{7}$

The estimation methodology involves two main questions regarding the choice of the empirical model and the face of the endogeneity problem.

a) To choose the empirical model, it can be considered that empirical analysis generally finds that the explanatory variables are correlated with individual unobservable effects. This makes the fixed-effect model preferable to the randomeffect model, because the former assumes that there is a correlation between the regressors and the individual fixed effects while the latter assumes the exogeneity of all the regressors with the individual effects. ${ }^{8}$ The Hausman test is generally performed to confirm this choice.

b) The endogeneity problem potentially arises from the inclusion of the growth variable among the explanatory variables; it is due to the correlation of this variable with the error term. However, for a large panel, the side of error terms that is not explained by the individual effects tends to be very small and the correlation tends to become unimportant. The panel involved in this analysis is very large; consequently, the endogeneity problem can be neglected. ${ }^{9}$

Moreover, based on the preliminary investigations, the following actions are implemented:

- based on the Hausman tests, the null hypothesis cannot be rejected and there is a correlation between the explanatory variables and the individual unobservable effect; therefore, the fixed-effect panel model is chosen;

\footnotetext{
${ }^{7}$ The logarithm transformation limits the calculations to those observations showing positive profit rates, and this choice cannot be made without effects on the estimate. Nevertheless, we believe that these effects can be neglected, because restricting the data set to complete budget firms and managing the outliers reduce their impacts, since, for the purposes of this analysis, they are believed to be only partially relevant.

${ }^{8}$ Under the fixed-effect hypothesis, the model is preliminarily transformed to eliminate the fixed effects; then, the OLS estimation is performed. This is because the fixed-effect model is defined by LSDVs (least squares dummy variables).

${ }^{9}$ In fixed- (or random-) effect models, the error, the estimate inconsistency, arises from the correlation between the lagged variable and $\mu_{i, j-1}$. For a large panel, the error term becomes very small; consequently, the correlation of the lagged variable with the error term becomes very small too; the endogeneity problem becomes insignificant because the estimates are consistent (Nickell, 1981).
} 
- the outlier analysis advises dropping the observations placed lower than the tenth percentile as well as those greater than the ninetieth percentile of the increasing asset distribution;

- the industrial effects $\left(\alpha_{h}\right)$ are not always significant, even if statistical acceptance is fixed at levels lower than the standard. This confirms that there are no significant differences in the industrial impacts on firm leverage. ${ }^{10}$ For this reason, the previous empirical model supports only very significant temporal effects $\left(\alpha_{J}\right)$ as well as individual effects $\left(\alpha_{i}\right)$;

- since there is a very close correlation between the size (assets and employees) and age variables and the inclusion of both in the explanatory variable set makes one of them systematically insignificant, an interaction variable is considered. Therefore, the previous 1) and 2) variables are replaced by:

h) Size-age interaction ( $\left.S I Z E \_A G E\right)$ : two different variables are considered: a) the interaction of assets by age $\left(A S S^{*} A G E\right)$ and b) the interaction of employee numbers by age $\left(E M P^{*} A G E\right)$.

\section{ANALYSIS OUTCOMES AND DISCUSSION}

The estimates for the models produced by the two different specifications of the interaction variables ( $A S S_{-} A G E$ and $E M P_{-} A G E$ ) are not very different, while there are noticeable differences in the outcomes of the models with the two measures of the profit rates. Therefore, to facilitate the following analysis, we shall limit ourselves to examining the findings of the models in which there are EMP_AGE interaction variables as well as the two different profit rates (ROI and $R O E)$ :

$$
\begin{aligned}
& \text { [2] } L E V^{S}=\beta^{1}\left(E M P_{-} A G E\right)_{i, j}+\beta^{2} G R O W_{i, j}+\beta^{3} P R O F_{i, j}^{S}+\beta^{4} T A N G_{i, j}+ \\
& \beta^{5} R I S K_{i, j}+\beta^{6} R E G_{i, j}+\alpha_{i}+\alpha_{j}+\mu_{i, j}
\end{aligned}
$$

Table 3 shows the correlation matrices that allow a preliminary evaluation. It can be confirmed that the multicollinearity problem has been partially solved. In the Italy sample, the correlation of the size-age interaction variable is low, as are the values of the other variables. Indeed, the same correlation is relatively higher for the southern subsample while all the other correlations are acceptable.

\footnotetext{
10 This reaffirms the findings of the previous analysis. For example, in their study based on a wide sample of U.S. companies, MacKay and Philips find that industry effects explain far less of the variation in financial structure than firm fixed effects. Cassar and Holmes also discover that industry effects have very limited impacts on firms' leverage and that they do not improve the explicative capacity of the model (Cassar and Holmes, 2003; MacKay and Philips, 2005).
} 


\begin{tabular}{|c|c|c|c|c|c|}
\hline \multicolumn{6}{|c|}{ Tab. 3 - Correlation Matrices } \\
\hline & \multicolumn{5}{|c|}{ ITALY } \\
\hline & EMP-AGE & GRO & $\mathrm{ROI}$ & TAN & RISK \\
\hline EMP-AGE & 1,0000 & & & & \\
\hline GRO & 0,0052 & 1,0000 & & & \\
\hline $\mathrm{ROI}$ & 0,0047 & 0,0023 & 1,0000 & & \\
\hline TAN & 0,0030 & 0,0285 & 0,1211 & 1,0000 & \\
\hline \multirow[t]{2}{*}{ RISK } & $-0,0032$ & 0,0059 & $-0,0939$ & 0,0229 & 1,0000 \\
\hline & EMP-AGE & GRO & ROE & TAN & RISK \\
\hline EMP-AGE & 1,0000 & & & & \\
\hline GRO & $-0,0070$ & 1,0000 & & & \\
\hline ROE & $-0,0083$ & $-0,0014$ & 1,0000 & & \\
\hline TAN & $-0,0025$ & 0,0001 & 0,1307 & 1,0000 & \\
\hline \multirow[t]{3}{*}{ RISK } & 0,0061 & $-0,0032$ & $-0,1091$ & 0,0299 & 1,0000 \\
\hline & \multicolumn{5}{|c|}{ SOUTH } \\
\hline & EMP-AGE & GRO & $\mathrm{ROI}$ & TAN & RISK \\
\hline EMP-AGE & 1,0000 & & & & \\
\hline GRO & 0,0223 & 1,0000 & & & \\
\hline $\mathrm{ROI}$ & 0,0299 & 0,0126 & 1,0000 & & \\
\hline TAN & $-0,0091$ & $-0,0046$ & 0,1330 & 1,0000 & \\
\hline \multirow[t]{2}{*}{ RISK } & $-0,0089$ & 0,0122 & $-0,0736$ & 0,0270 & 1,0000 \\
\hline & EMP-AGE & GRO & $\mathrm{ROE}$ & TAN & RISK \\
\hline EMP-AGE & 1,0000 & & & & \\
\hline GRO & 0,0137 & 1,0000 & & & \\
\hline ROE & 0,0057 & 0,0086 & 1,0000 & & \\
\hline TAN & 0,0071 & $-0,0130$ & 0,1419 & 1,0000 & \\
\hline \multirow[t]{3}{*}{ RISK } & 0,0132 & 0,0011 & $-0,0964$ & 0,0332 & 1,0000 \\
\hline & \multicolumn{5}{|c|}{ NORTH } \\
\hline & EMP-AGE & GRO & $\mathrm{ROI}$ & TAN & RISK \\
\hline EMP-AGE & 1,0000 & & & & \\
\hline GRO & 0,0040 & 1,0000 & & & \\
\hline ROI & 0,0008 & 0,0011 & 1,0000 & & \\
\hline TAN & 0,0046 & $-0,0320$ & 0,1187 & 1,0000 & \\
\hline \multirow[t]{2}{*}{ RISK } & $-0,0022$ & 0,0040 & $-0,0970$ & 0,0225 & 1,0000 \\
\hline & EMP-AGE & GRO & $\mathrm{ROI}$ & TAN & RISK \\
\hline EMP-AGE & 1,0000 & & & & \\
\hline GRO & $-0,0110$ & 1,0000 & & & \\
\hline ROE & $-0,0096$ & $-0,0024$ & 1,0000 & & \\
\hline TAN & $-0,0037$ & 0,0021 & 0,1298 & 1,0000 & \\
\hline RISK & 0,0054 & $-0,0037$ & 0,1108 & 0,0298 & 1,0000 \\
\hline
\end{tabular}

Table 4 shows the statistics of the variables.

The OLS estimates of this unbalanced fixed-effect panel are satisfactory; the diagnostic tests are held at standard significance levels. Tables $5 \mathrm{a}$ and $5 \mathrm{~b}$ show the outcomes for the two models.

Starting with the regional dummy coefficients of the ITALY model, it can be noted that the elasticity for the total leverage, as measured by the total debts on equity (TFD/EQU), is lower for southern firms than for other Italian firms. This is the effect of two opposing tendencies: on the one hand, the elasticity of short-term debt leverage (SFD/EQU), which is lower for southern firms, and, on the other hand, the elasticity of the long-term debt leverage 


\begin{tabular}{|c|c|c|c|c|c|c|c|}
\hline & AVERAGE & ST. DEV. & MIN. & MAX. & $\mathrm{N}^{\circ} \mathrm{OBS}$ & GROUPS & OBS/GROU \\
\hline \multicolumn{8}{|c|}{ ITALY } \\
\hline In ASS & 14,77 & 1,40 & 4,61 & 21,64 & 427468 & 63631 & 6,83 \\
\hline In EMP & 2,85 & 1,03 & $-0,69$ & 5,52 & 427468 & 63631 & 6,83 \\
\hline In ETA & 3,40 & 0,34 & 1,79 & 5,20 & 427468 & 63631 & 6,83 \\
\hline In GRO & 4,63 & 1,11 & $-6,77$ & 7,11 & 218880 & 39056 & 5,60 \\
\hline In ROI & 2,08 & 1,19 & $-10,69$ & 10,12 & 277658 & 55298 & 5,02 \\
\hline In ROE & 1,73 & 1,57 & $-10,38$ & 10,21 & 312240 & 57110 & 5,47 \\
\hline In TNG & 24,53 & 19,91 & 0,00 & 99,80 & 427468 & 62631 & 6,83 \\
\hline In RSK & 1,06 & 1,05 & $-8,94$ & 10,75 & 424664 & 61507 & 6,90 \\
\hline \multicolumn{8}{|c|}{ SOUTH } \\
\hline In ASS & 14,71 & 1,41 & 4,61 & 20,04 & 54102 & 8968 & 6,03 \\
\hline In EMP & 2,65 & 1,04 & 0,69 & 5,52 & 54102 & 8968 & 6,03 \\
\hline In ETA & 3,29 & 0,32 & 2,40 & 4,73 & 54102 & 8968 & 6,03 \\
\hline In GRO & 4,63 & 1,10 & $-3,99$ & 6,72 & 27825 & 5418 & 4,85 \\
\hline In ROI & 1,78 & 1,24 & $-7,11$ & 9,79 & 30211 & 7141 & 4,23 \\
\hline In ROE & 1,20 & 1,70 & $-10,38$ & 8,27 & 36732 & 7715 & 4,76 \\
\hline In TNG & 32,45 & 21,82 & 0,00 & 99,57 & 54102 & 8968 & 6,03 \\
\hline In RSK & 0,88 & 1,13 & $-8,94$ & 8,75 & 52977 & 8580 & 6,17 \\
\hline \multicolumn{8}{|c|}{ NORTH } \\
\hline In ASS & 14,8 & 1,4 & 6,9 & 21,6 & 373366 & 53849 & 6,93 \\
\hline In EMP & 2,9 & 1,0 & $-0,7$ & 5,5 & 373366 & 53849 & 6,93 \\
\hline In ETA & 3,4 & 0,3 & 1,8 & 5,2 & 373366 & 53849 & 6,93 \\
\hline In GRO & 4,6 & 1,1 & $-6,8$ & 7,1 & 191055 & 33767 & 5,66 \\
\hline In ROI & 2,1 & 1,2 & $-10,7$ & 10,1 & 247447,0 & 48260 & 5,13 \\
\hline In ROE & 1,8 & 1,5 & $-9,6$ & 10,2 & 275508,0 & 49520 & 5,56 \\
\hline In TNG & 23,4 & 19,3 & 0,0 & 99,8 & 373366 & 53489 & 6,93 \\
\hline In RSK & 1,1 & 1,0 & $-7,9$ & 10,7 & 371687 & 53109 & 7,00 \\
\hline
\end{tabular}

Source: Italian Institut of Statistics ISTAT)

( $L D F / E Q U)$, which is instead higher than that of other firms. The firms of the Italian Mezzogiorno always show greater elasticity for bank debt leverage (TBD/EQU), because they are highly dependent on bank credit.

The direction of the relationships with the other variables is as expected. Both the models find that the interaction variable coefficients are positive, and this is probably due to the size effect, which is expected to be positive, dominating the age effect, which might be ambiguous.

The leverage-profitability relationship differs in accordance with the various earning rates. When the earning rate is measured by the ROI, the outcomes reveal noticeable differences: the relationship is negative for the northern regional model, with the exception of long-term debt leverage; for southern firms, the positive relationship prevails, the only exception being the short-term debt leverage model. It should be noted that, for southern SMEs, the coefficient of the bank leverage model is zero. These outcomes seem to confirm the predictions of the pecking order approach but reveal some important differences in the regional models. For example, it is clear that retained earnings must be seen as the alternative financial source to short-term debts, and it is confirmed that, when profitability increases, the share of long-term debts rises. However, while the total debt leverage increases for northern firms, the downward trend prevails for southern firms. Moreover, for northern firms, the relationship between bank debt leverage and earning rates is systematically negative, proving the substitution between the two financial sources; for 
southern firms, this relationship is not verified in the $R O I$ models. Finally, it should be noted that, in the ROE model, the profitability tends to have a positive effect on the different measures of leverage, the exception being the case of bank leverage models, in which a negative relationship prevails. ${ }^{11}$

Regarding the remaining relationships, the risk variable coefficients are always negative, and this appears to be consistent with the predictions of the main theoretical approaches. There is also a negative relationship between the various leverage measures and the variable asset structure, that is, the share of fixed assets, the exception being the long-term debt leverage, which is positive. On the contrary, for southern firms, the relationship is systematically negative. This is probably because the long-term effect, which is expected to be positive because fixed assets can be used as collateral, dominates the negative short-term effect.

Both the estimated impact of the explicative variables and the unexplored effects of the omitted variables can explain the structural differences between the northern and the southern model. An F statistic can be useful for testing for the existence of these structural differences. The statistic is built comparing two kinds of model: the ITALY "restricted" model, in which the coefficients are "constrained" to be equal for all firms, and the NORTH and SOUTH "non-restricted" models, in which the coefficients for the firms of the two subsamples can be different. ${ }^{12}$

The $\mathrm{F}$ test is as follows:

$$
F=\frac{\left(R S S_{I}-R S S_{S}-R S S_{N}\right) /(m-1) k}{\left(R S S_{I}+R S S_{S}+R S S_{N}\right) /(n-1) k}
$$

where RSS, is the residual sum of squares for the "restricted" model (ITALY), RSSs and $R S S_{N}$ the residual sums of squares for the "non-restricted" models (SOUTH and NORTH), $m$ the number of "restricted" equations, $n$ the observations and $k$ the number of explicative variables. The null hypothesis is that the estimated coefficients of the "restricted" model are equal to those of the two "non-restricted" models, and the alternative hypothesis is that they are different.

The last row of Table 5 contains the $F$ statistic and the p-values. Although the determinants of the capital structure as much as the direction of their relationship with leverage are approximately equal, the alternative hypothesis must always be accepted for both the models at the conventional significance level.

\footnotetext{
11 This result can partially be explained by the restriction of the sample to profitable firms only.

12 Similar F tests occur in the cited works by Hall et al. (2004) and more recently Psillaki and Daskalakis (2009) to test differences in country effects.
} 


\begin{tabular}{|c|c|c|c|c|c|c|c|c|c|c|c|c|}
\hline \multicolumn{13}{|c|}{ Tab. 5a - Panel estimation (ROI) [2001-2013 years] } \\
\hline & \multicolumn{4}{|c|}{ ITALY } & \multicolumn{4}{|c|}{ SOUTH } & \multicolumn{4}{|c|}{ NORTH } \\
\hline & $\begin{array}{c}{[1]} \\
\text { DFT/EQU }\end{array}$ & $\begin{array}{c}\text { [2] } \\
\text { SFD/EQU }\end{array}$ & $\begin{array}{c}{[3]} \\
\text { LFD/EQU }\end{array}$ & $\begin{array}{c}{[4]} \\
\text { DBT/EQU }\end{array}$ & $\begin{array}{c}{[1]} \\
\text { DFT/EQU }\end{array}$ & $\begin{array}{c}{[2]} \\
\text { SFD/EQU }\end{array}$ & $\begin{array}{c}{[3]} \\
\text { LFD/EQU }\end{array}$ & $\begin{array}{c}{[4]} \\
\text { DBT/EQU } \\
\end{array}$ & $\begin{array}{c}{[1]} \\
\text { DFT/EQU }\end{array}$ & $\begin{array}{c}{[2]} \\
\text { SFD/EQU }\end{array}$ & $\begin{array}{c}{[3]} \\
\text { LFD/EQU }\end{array}$ & $\begin{array}{c}{[4]} \\
\text { DBT/EQU } \\
\end{array}$ \\
\hline $\begin{array}{l}\text { EMPLOYMENT-AGE } \\
\text { INTERACTION }\end{array}$ & 0.035 & 0.029 & 0.044 & 0.051 & 0.033 & 0.033 & 0.021 & 0.085 & 0.037 & 0.030 & 0.050 & 0.044 \\
\hline & $(.002)^{* \star *}$ & $(.003)^{\star \star \star}$ & $(.005)^{* \star *}$ & $(.005)^{\star \star \star}$ & $(.005)^{* \star *}$ & $(.006)^{* \star *}$ & $(.011)^{\star}$ & $(.010)^{\star * *}$ & $(.003)^{\star \star \star}$ & $(.003)^{* \star \star}$ & $(.006)^{\star \star \star}$ & $(.006)^{\star \star \star}$ \\
\hline GROWTH & 0.019 & 0.016 & 0.031 & 0.027 & 0.034 & -0.015 & 0.067 & 0.046 & 0.018 & 0.015 & 0.025 & 0.026 \\
\hline & $(.002)^{* * *}$ & $(.003)^{\star \star \star}$ & $(.006)^{* \star *}$ & $(.006)^{* \star \star}$ & $(.007)^{\star \star \star}$ & $(.008)^{*}$ & $(.017)^{\star \star \star}$ & $(.016)^{\star \star \star}$ & $(.003)^{\star * \star}$ & $(.003)^{\star \star \star}$ & $(.006)^{\star \star \star}$ & $(.006)^{\star \star \star *}$ \\
\hline ROI & $\begin{array}{l}-0.017 \\
(.002)^{\star \star \star *}\end{array}$ & $\begin{array}{l}-0.035 \\
(.002)^{* * *}\end{array}$ & $\begin{array}{c}0.029 \\
(.004)^{\star \star \star \star}\end{array}$ & $\begin{array}{l}-0.065 \\
(.004)^{* * *}\end{array}$ & $\begin{array}{l}0.007 \\
(.005)\end{array}$ & $\begin{array}{l}-0.016 \\
(.006)^{\star \star \star *}\end{array}$ & $\begin{array}{c}0.062 \\
(.011)^{\star \star \star *}\end{array}$ & $\begin{array}{l}0.001 \\
(.011)\end{array}$ & $\begin{array}{c}-0.021 \\
(.002)^{\star \star \star \star}\end{array}$ & $\begin{array}{c}-0.037 \\
(.002)^{* \star *}\end{array}$ & $\begin{array}{c}0.023 \\
(.004)^{* \star \star}\end{array}$ & $\begin{array}{c}-0.075 \\
(.004)^{\star \star \star *}\end{array}$ \\
\hline ASSET STRUCTURE & -0.007 & -0.012 & 0.002 & -0.004 & -0.009 & -0.014 & -0.005 & -0.003 & -0.007 & -0.012 & 0.003 & -0.004 \\
\hline & $(.000)^{\star * \star}$ & $(.000)^{\star * *}$ & $(.000)^{* *}$ & $(.000)^{\star * *}$ & $(.001)^{\star \star \star}$ & $(.001)^{\star \star \star}$ & $(.001)^{\star \star \star *}$ & $(.001)^{* *}$ & $(.000)^{* * *}$ & $(.000)^{\star \star \star}$ & $(.001)^{\star \star *}$ & $(.001)^{\star \star \star}$ \\
\hline RISK & $\begin{array}{l}-0.020 \\
(.002)^{\star \star \star}\end{array}$ & $\begin{array}{l}-0.015 \\
(.002)^{* * *}\end{array}$ & $\begin{array}{l}-0.026 \\
(.004)^{\star \star *}\end{array}$ & $\begin{array}{l}-0.039 \\
(.004)^{* * *}\end{array}$ & $\begin{array}{l}-0.014 \\
(.005)^{* *}\end{array}$ & $\begin{array}{l}-0.006 \\
(.006)\end{array}$ & $\begin{array}{l}-0.020 \\
(.012)^{*}\end{array}$ & $\begin{array}{l}-0.029 \\
(.011)^{* *}\end{array}$ & $\begin{array}{l}-0.020 \\
(.002)^{\star \star \star}\end{array}$ & $\begin{array}{c}-0.015 \\
(.002)^{\star \star \star}\end{array}$ & $\begin{array}{l}-0.027 \\
(.005)^{* \star *}\end{array}$ & $\begin{array}{c}-0.039 \\
(.005)^{\star \star *}\end{array}$ \\
\hline REGIONAL DUMMY & $\begin{array}{l}-0.060 \\
(.057)\end{array}$ & $\begin{array}{l}-0.102 \\
(.052)^{*}\end{array}$ & $\begin{array}{l}0.120 \\
(.132)\end{array}$ & $\begin{array}{l}0.023 \\
(.124)\end{array}$ & & & & & & & & \\
\hline$R^{2}$ within & 0.113 & 0.117 & 0.028 & 0.056 & 0.058 & 0.063 & 0.022 & 0.040 & 0.128 & 0.127 & 0.030 & 0.061 \\
\hline between & 0.003 & 0.015 & 0.006 & 0.000 & 0.008 & 0.030 & 0.004 & 0.001 & 0.004 & 0.012 & 0.006 & 0.000 \\
\hline overall & 0.008 & 0.019 & 0.009 & 0.006 & 0.010 & 0.032 & 0.005 & 0.008 & 0.013 & 0.020 & 0.008 & 0.007 \\
\hline $\mathrm{F}$ & 854.1 & 893.9 & 130.7 & 333.1 & 46.3 & 50.3 & 13.0 & 27.5 & 947.0 & 938.8 & 130.3 & 343.0 \\
\hline$F\left(\right.$ for all $\left.u_{i}\right)$ & 23.2 & 19.4 & 10.6 & 12.3 & 19.2 & 15.3 & 10.1 & 10.2 & 23.6 & 20.0 & 10.8 & 12.4 \\
\hline$\sigma_{u}$ & 1.223 & 1.271 & 1.918 & 2.060 & 1.121 & 1.209 & 1.934 & 1.894 & 1.245 & 1.279 & 1.914 & 2.081 \\
\hline$\sigma_{e}$ & 0.506 & 0.567 & 0.984 & 1.040 & 0.474 & 0.555 & 0.956 & 0.987 & 0.509 & 0.565 & 0.985 & 1.048 \\
\hline$\rho$ & 0.854 & 0.834 & 0.791 & 0.797 & 0.848 & 0.826 & 0.805 & 0.786 & 0.856 & 0.837 & 0.791 & 0.798 \\
\hline OBS & 140281 & 141236 & 98936 & 118920 & 15398 & 15339 & 11966 & 13881 & 126339 & 125897 & 86970 & 106163 \\
\hline GROUPS & 32784 & 33114 & 26306 & 29786 & 4065 & 4055 & 3356 & 3745 & 29164 & 29133 & 23002 & 26415 \\
\hline $\begin{array}{l}\text { F test for structural } \\
\text { differences }\end{array}$ & $F=194,3$ & $F=185,7$ & $\mathrm{~F}=89,9$ & $F=110,1$ & & & & & & & & \\
\hline
\end{tabular}




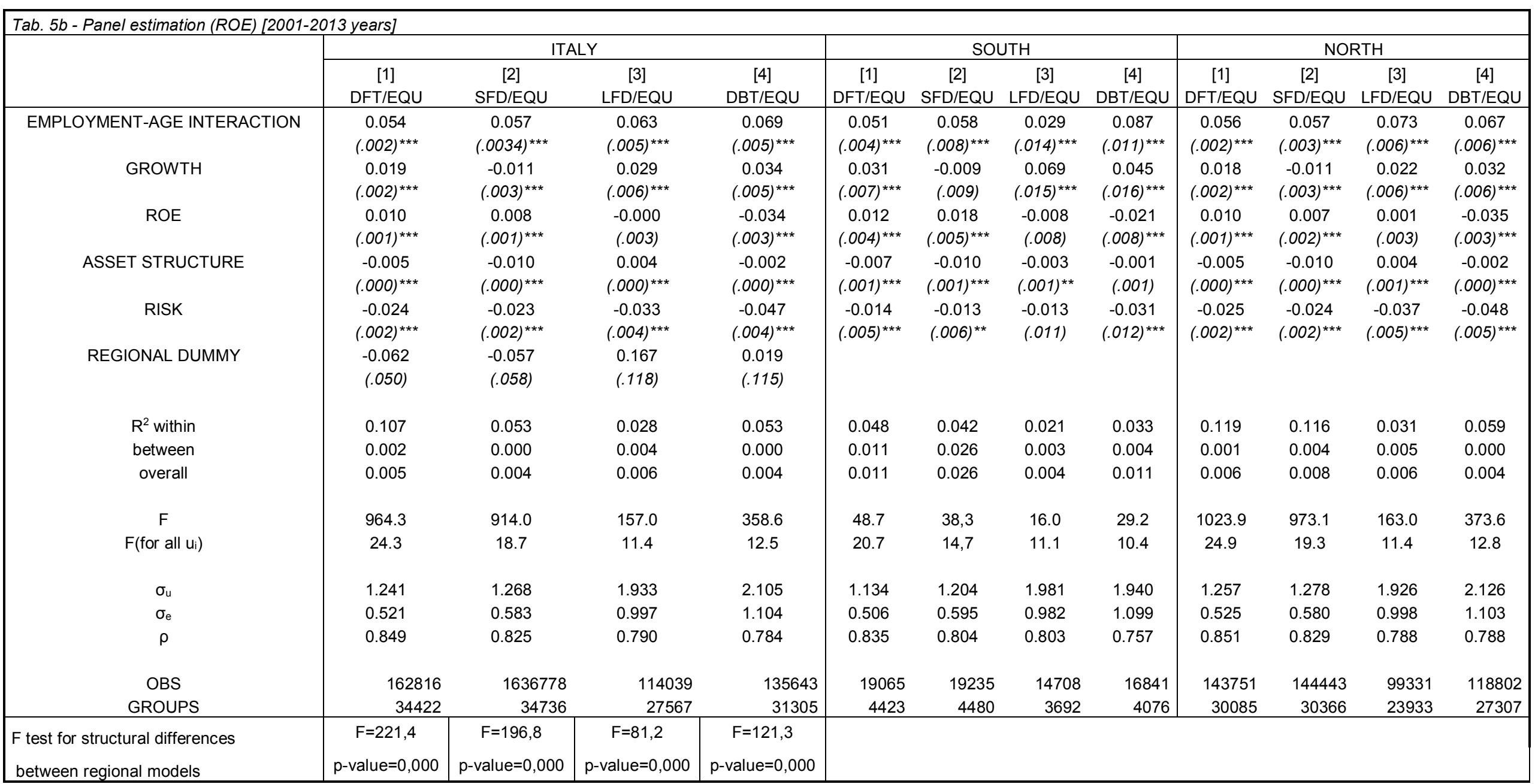




\section{SOME CONCLUDING REMARKS}

The financial strategies of firms arise from very complex processes, and the theoretical approaches of capital structure analysis seem to be insufficient to provide a comprehensive understanding. Similarly, the empirical model appears to be partially effective for analyses of firms' financial choices.

As with most of the empirical studies on firms' capital structure, the previous analysis is significantly affected by the sample used for the empirical analysis. Like those, this analysis reaffirms that the standard leverage model is partially able to analyse firms' financial choice because of the predominance attached to the fixed effects. This is consistent with the information asymmetry approach, but it still suggests that the weight of the omitted variable is great. Nevertheless, the findings allow us to expand the knowledge about the capital structure of firms in backward areas.

By investigating a large sample of SMEs in the Italian Mezzogiorno - the perfectly integrated but slow-growing area of the south of the country - several significant differences in the regional leverage model are found. Some of these reaffirm that it is known, for example, that, for firms in backward areas, the propensity to use financial leverage is lower and the propensity to use bank leverage is significantly higher. This is because firms face greater difficulties in resorting to alternative financial sources. One of the main effects is that firms are more dependent on internal finance, as the relatively reduced impact of the growth variable on leverage proves. Other findings are equally noticeable, but it seems that they are affected by the dramatic events at the end of the previous decade. They indicate that, after the credit shock and the dramatic fall in business, debt reorganization occurred so that the propensity for long-term indebtedness increased because of its partial substitution for short-term debts.

Nevertheless, based on the outcomes of the fixed-effect panel model, other findings seem to emerge, suggesting more important structural differences in the working of the regional leverage models. Despite the fact that the impacts of the size and age variables on southern firms' leverage are not significantly different, the elasticity of the profit rate and risk variables are unexpectedly lower than those for firms from other regions.

This evidence is coherent with the analysis of the distinctive features of the financial structure of Mezzogiorno SMEs. It shows that southern firms are unexpectedly overcapitalized, because the share of equity is very much larger. The different behaviour of the impact on leverage of the profit ratios and the asset structure variables in the regional models confirms that the overcapitalization (or overcapacity) is not entirely explained by the very probable presence of a large informal area or by equally probable accounting constraints related to the incentives promoting local firm investments. There is a suspicion that they may represent the conditions that warrant the activities of firms in areas showing slower growth but are perfectly integrated into domestic and foreign financial markets. The difficulty involved in accessing other financial sources makes firms more dependent on bank resources, and firms have to choose the capital structure that best facilitates their relationship with the banking system. If possibilities for financial management flexibility arise, this condition nevertheless confines firms to inefficiency, because it is not hard to imagine 
how much firms' opportunity for growth and propensity for innovation are precluded by this. The evidence emerging from the preliminary analysis of the effects on the financial crisis seems to confirm this hypothesis, because it shows that the differences in the regional capital structure became more marked in the years following the crisis.

\section{REFERENCES}

1) Levine R. (1997) - Financial Development and Economic Growth: Views and Agenda, Journal of Economic Literature, 35 (2):688-726;

2) Levine R. (2004) - Finance and Growth: Theory, Evidences and Mechanism, NBER, WP n.10766;

3) MacKay P., G.M. Philips (2005) - "How does Industry Affect Firm Financial Structure?", Review of Financial Studies, 18:1433-1466;

4) Matias F., Serrasqueiro Z. (2017) - "Are there Reliable Determinant Factors of Capital Structure Decisions? Empirical Study of SMEs in Different regions of Portugal", Research in International Business and Finance, 40: 19-33;

5) Mazur K. (2007) - "The Determinants of Capital Structure Choice: Evidence from Polish Companies; International Advance in Economic Research, 13: 493-514;

6) Mediocredito Centrale (ed) (1997) - Indagine sulle imprese manifatturiere, VI rapporto, Milano, II Sole24 Ore;

7) Mediocredito Centrale (ed) (2000) - Indagine sulle imprese manifatturiere, VII rapporto, Milano, II Sole24 Ore;

8) Michaelas N., F. Chittenden, P. Poutziouris (1999) -“Financial Policy and Capital Structure Choice in UK SMEs: Empirical Evidence from Company Panel Data", Small Business Economics, 12: 113-130;

9) Miller M.H. (1977) - Debt and Taxes, The Journal of Finance, 32(2):261-275;

10) Modigliani F., M. Miller (1958)- "The Cost of Capital, Corporation Finance and the Theory of Investment", American Economic Review, 48(3): 261-297;

11) Modigliani F., M. Miller (1961)- "Dividend Policy, Growth and the Evaluation of Shares", Journal of Business, 34 (4): 411-433;

12) Myers C. S. (1977) - "Determinants of Corporate Borrowing", Journal of Financial Economics, 5:147175 ;

13) Myers C. S. (1984) - "The Capital Structure Puzzle"; The Journal of Finance, 39(3): 574-592;

14) Myers C.S., N.S. Majluf (1984) - "Corporate Financing and Investment Decisions when Firms Have Information that Investors do not Have", Journal of Financial Economics, 13(2):187-221;

15) Nickell S. (1981) - "Biases in Dynamic Model With Fixed effects", Econometrica, 1417-1426;

16) Noulas A., G. Genimakis (2011) - The Determinants of Capital Structure Choice: Evidence from Greek Listed Companies, Applied Financial Economics, 21: 379-387;

17) Palacin-Sanchez M.J., Ramirez-Herrera L.M., Di Pietro F. (2013), "Capital Structure of SMEs in Spanish Regions, Small Business Economics, 41: 503-519;

18) Palacin-Sanchez M.J., Di Pietro F., (2016) - "The Role of the Regional Financial Sector in the Capital Structure of Small and Medium-Sized Enterprises (SMEs)", Regional Studies, 50 (7): 1232-1247;

19) Presbitero A., G. Udell, A. Zazzaro (2014) - The Home Bias and the Credit Crunch: A regional Perspective, Journal of Money, Credit and Banking. 46(1):53-85;

20) Psillaki M., N. Daskalakis (2009) - "Are the Determinants of Capital Structure Country or Firm Specific?", Small Business Economics, 33:319-333;

21) Qureshi M. A. (2009) - "Does Pecking Order Theory Explain Leverage behavior in Pakistan", Applied Financial Economics, 19:1365-1370;

22) Rajan R. G., Zingales L. (1995) - "What do we know about Capital Structure? Some Evidence from International Data", The Journal of Finance, 50 (?). 1421-1460; 
23) Ross S. A. (1977) The Determination of Financial Structure: The Incentive-Signaling Approach, The Bell Journal of Economics, 8(1): 23-40;

24) Sarno D. (2008) - "Capital Structure and Growth of the Firms in the Backward Region of the South Italy", Applied Financial Economics, 18:821-833;

25) Sarno D. "Sviluppo finanziario e crescita economica nel Mezzogiorno", Milano, Franco Angeli, 2009;

26) Tong G. Q., C. J. Green (2005) - "Pecking Order or Trade-off Hypothesis? Evidence on Capital Structure of Chinese Companies", Applied Economics, 37: 279-2189;

27) Yu D., Aquino R. (2009) - "Testing Capital Structure Models on Philippine Listed Firms, Applied Economics, 41:1973-1990;

28) Wald J.K. (1999) - "How firm Characteristics Affect Capital Structure: an International Comparison" Journal of Financial Research, 22(2): 161-187; 